\title{
Algae and Cyanobacteria in Soils of Moscow
}

\author{
Marina F. Dorokhova*, Natalia E. Kosheleva, Elena V. Terskaya \\ Department of Landscape Geochemistry and Soil Geography, Faculty of Geography, Lomonosov Moscow State \\ University, Moscow, Russia \\ Email: "dorochova@mail.ru
}

Received 22 July 2015; accepted 27 September 2015; published 30 September 2015

Copyright (C 2015 by authors and Scientific Research Publishing Inc.

This work is licensed under the Creative Commons Attribution International License (CC BY). http://creativecommons.org/licenses/by/4.0/

(c) (i) Open Access

\begin{abstract}
Algal-cyanobacterial communities, soil nano- and microfauna, and mycelium of micromycetes were studied in soils of an administrative district of Moscow. To characterize the habitat conditions of microbiota in the soils of different functional zones of the city, the acid-base conditions and the contents of exchangeable and water-soluble nitrogen, mobile heavy metals, and soluble salts were determined. The diversity of species of algal-cyanobacterial communities, the composition of the dominant species, the proportions of different ecological groups of diatom algae, the diversity of soil nano- and microfauna, and the abundance of colorless and colored mycelium in the urban soils were characterized. The analysis of these parameters showed that the degree of technogenic impact on soil microbiota decreases in the following sequence of functional zones of the city: industrial > traffic > residential > recreation.
\end{abstract}

\section{Keywords}

Urban Soils, Salinization, Pollution, Microbiota, Algae, Cyanobacteria, Moscow, East European Plain

\section{Introduction}

Microscopic algae and cyanobacteria are permanent components of terrestrial phytocenoses, where they form the phototropic block of the soil microbial cenosis. They inhabit both natural and anthropogenically modified soils.

Urban soils develop under the strong influence of anthropogenic factors and, hence, significantly differ in the main physical and physicochemical properties from the natural zonal soils [1] [2]. The microscopic inhabitants of the urban soils are very responsive to the anthropogenic transformation of their properties, which affects the parameters of algal-cyanobacterial communities [3] [4], as well as the diversity and composition of soil inverte-

"Corresponding author. 
brates [5]-[7] and microscopic fungi [8]-[10]. This determines the suitability of these groups of soil organisms as indicators of the state of urban soils [10]-[13].

The studies of algal-cyanobacterial communities are performed in several cities of Russia (Monchegorsk and Ekaterinburg [14], Ufa [3] [15], Krasnoyarsk [16], and Kirov [17]) and Ukraine (Lugansk [18] and Mariupol [19]). Algae and cyanobacteria in the urban recreation zones and on the lawns near motor roads are best understood. Most works deal with flora problems; only few authors also studies the urban soils and discuss the effect of their physicochemical properties on the composition of soil algae and cyanobacteria [18] [20]. Little data are still available on the impact of heavy metals (HMs) and deicing salt agents accumulated in the urban soils on the algal-cyanobacterial communities.

The study objectives are to: 1 ) acquire data on the main physicochemical parameters of urban soils, the content and composition of water-soluble salts, and the content of HMs available to microbiota; 2) reveal the main features of algal-cyanobacterial communities; 3 ) determine the composition and abundance of nano- and microfauna and microscopic fungi; and 4) reveal the parameters of urban soils affecting the algal-cyanobacterial communities.

\section{Materials and Methods}

\subsection{Study Area}

The studies were performed in the Northwestern Administrative District of Moscow, the capital of Russia. The city is located in the taiga zone on the Smolensk-Moscow Upland in the central part of the East European Plain.

This is an accretion-erosion plain with an altitude of 160 - $180 \mathrm{~m}$, composed of fluvioglacial and moraine deposits. Such landscapes are characteristic of Northwestern part of Moscow. The climate is moderately continen$\mathrm{tal}$; the mean annual air temperature is $+5.4^{\circ} \mathrm{C}$; the mean annual precipitation is $700 \mathrm{~mm}$. The summer is moderately warm; the mean temperature of July, the warmest month, is $+18.2^{\circ} \mathrm{C}$. The winter is moderately cold; the mean temperature of January, the coldest month, is $-9.3^{\circ} \mathrm{C}$; the freezing period (with the mean daily air temperature below $-5^{\circ} \mathrm{C}$ ) continues for about 100 days; the mean depth of the snow cover is $40-45 \mathrm{~cm}$.

Low- and medium-humus medium-thick urbanozems are prevalent in the soil cover; slightly disturbed soddypodzolic soils prevail in parks, and soddy-alluvial soils in small river valleys [21]. The urban soils represent a depositing medium for various pollutants, including HMs. In the study area, they arrive into soils from industrial enterprises, waste treatment facilities, thermal power plants, two interurban bus stations, and motor and rail transport [22]. In winter, deicing agents used for the treatment of highways, as well as roads within the residential and recreation zones, become additional pollution sources in the urban environment. Sodium chlorides are most frequently used for ice control on the roads. It was found [23]-[26] that these compounds cause the salinization of urban soils during the spring period.

Several land-use zones were identified within the studied region of Moscow: industrial, traffic (road and adjacent areas), residential (blocks of houses), and recreation (park, small river valley) zones. It is believed that each zone is characterized by a specific level of anthropogenic impact on the ecosystem [27]. The soils develop under sown grasses in the industrial, traffic, and residential zones; under forest phytocenoses (herbaceous pine forest, yellow archangel-herbaceous birch-linden forest, yellow archangel maple forest with pine) in the park; and under grassy-forb communities in the small river valley.

This part of Moscow was selected as the study location because within it there are all land-use zones, including industrial. This makes it possible to study the soils and the soil microbiota influenced by significantly different levels of anthropogenic impact in a compact area.

\subsection{Materials}

Objects of this study were soil algae, cyanobacteria, nano- and microfauna, and mycelium of micromycetes. For their study, soil samples were taken from a depth of $0-3 \mathrm{~cm}$ on 18 samples sites in different land-use zones in the late spring (May 2013) (Figure 1).

The diversity of algae and cyanobacteria was studied in soil cultures using the method of fouling glasses, which was first proposed by Lund [28] for the identification of soil diatoms but later became one of the main methods of studying other groups of algae and cyanobacteria in the soil [29] [30]. Each treatment included 5 sterile cover glasses for micropreparations; cultures were wetted with distilled water. The cultures were grown 


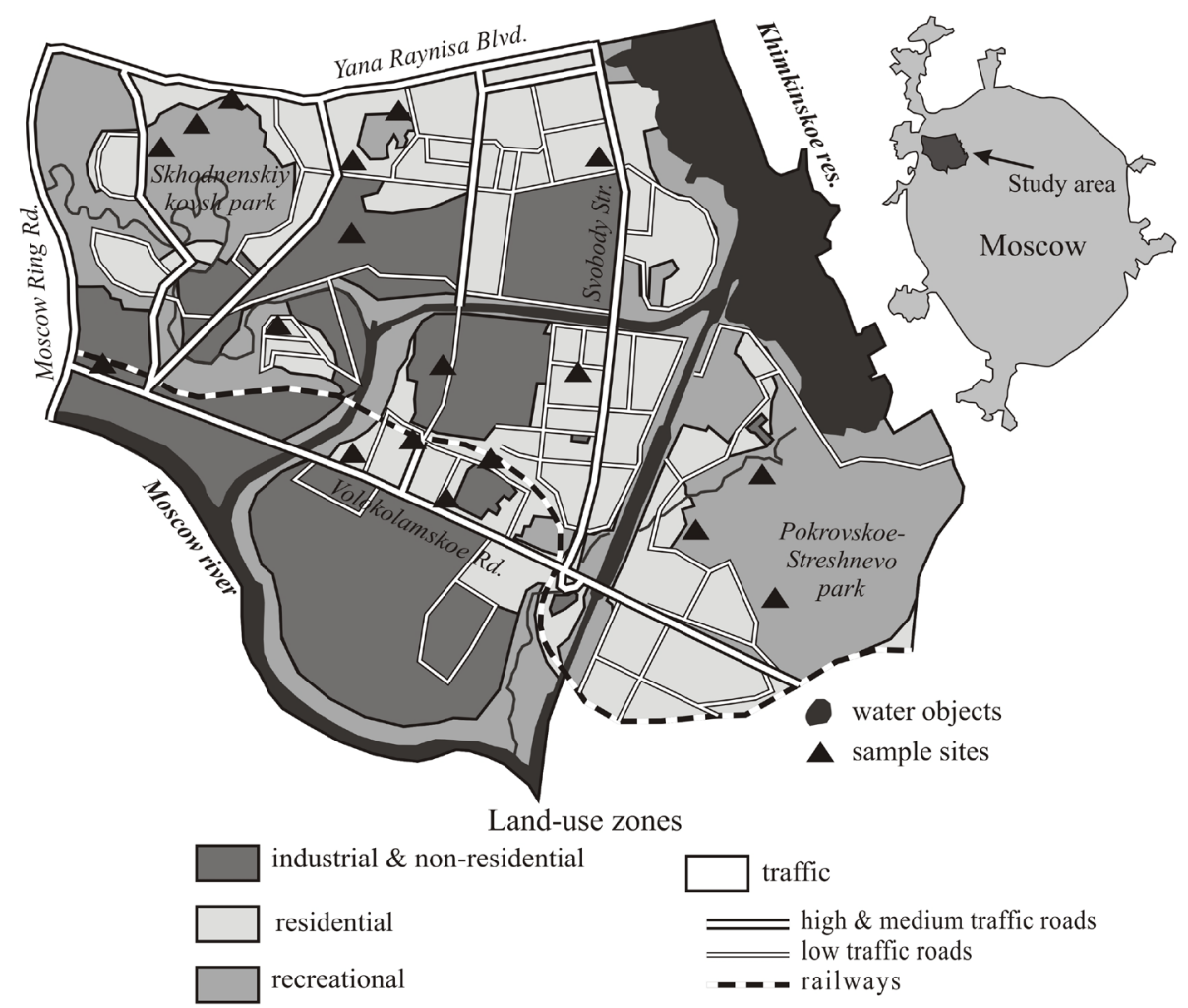

Figure 1. Study area with sampling sites in different land-use zones of the Northwestern district of Moscow.

under daylight at $20^{\circ} \mathrm{C}$ for a month, during which they were inspected five times. The species identification of diatom algae was performed in permanent preparations on the Elyashev medium using cover glasses ignited on a copper plate for $1.5 \mathrm{~h}$.

In the same cultures, the presence of nano- and microfauna and fungal mycelium was determined on fouling glasses. The species composition of algae and cyanobacteria was determined also using liquid cultures on the Bold medium [31]. The species composition of algae and cyanobacteria was identified using the conventional guides [32]-[35].

The content of HMs and the properties of soils on the same plots in different land-use zones were analyzed at the Ecological-Geochemical Center of the Faculty of Geography, Moscow State University. In the soil samples, the following physicochemical parameters were determined: $\mathrm{pH}_{\text {water }}$ and TDS in the water extract (soil:solution ratio 1:5) by potentiometry on a HANNA 2/3 instrument (the Netherlands); the anionic and cationic composition of water extract on a Staier ion chromatograph (Russia). Mobile forms of HMs of the first (Cd, $\mathrm{Pb}, \mathrm{Zn}$ ) and second (Co, $\mathrm{Cr}, \mathrm{Cu}, \mathrm{Ni}$ ) hazard classes were extracted with $1 \mathrm{~N}$ ammonium acetate buffer solution with EDTA (pH 4.8; soil:solution ratio 1:10); their content was determined by atomic absorption spectroscopy on a novAA400 spectrometer (Analytik-Jena AG, Germany) with flame ionization and an AA-240Z atomic absorption spectrometer (Varian, USA) with electrothermal atomization. Exchangeable ammonium was determined by the colorimetric TsINAO method on a Cary 60 spectrophotometer (Agilent Technologies, USA) [36].

\subsection{Data Analysis}

The following biological parameters were determined in soil cultures: the compositions and relative abundances of algae, cyanobacteria, and nano- and microfauna; the relative abundances of colorless and colored fungal mycelium; and the proportions of the ecological groups of diatom algae. The ecological parameters of indicator diatoms were borrowed from the monograph by Barinova et al. [37]. The abundances of microbial groups were determined using a five-point scale (magnification $10 \times 40$; for microfauna, $10 \times 25)$ : 1 ) rare $(1-10$ objects in the preparation); 2) quite often (10 - 50 objects); 3) frequent (10 - 25 objects in every 45 fields of view in the 
preparation); 4) very frequent (25 - 50 objects in every 45 fields of view in the preparation); 5) abundant (more than 50 objects in every 45 fields of view in the preparation) [38] with modification.

The similarity of the species compositions of algal-cyanobacterial communities in soils of different land-use zones was assessed from the Jaccard coefficient calculated using the Equation (1):

$$
K j=c /(a+b-c)
$$

where $a$ and $b$ denote the numbers of species on the first and second test plots, respectively, and $c$ is the number of common species for the both plots [39].

To assess the environmental hazard of soil contamination with mobile forms of HMs, the environmental hazard factor Ko was calculated using the Equation (2):

$$
K o=C / \mathrm{MPC}
$$

where $C$ is the content of the mobile forms of the element in the studied soil, and MPC is the maximum permissible concentration for the mobile forms of the element in soils. In conformity with Russian regulations [40], the following MPC values were taken for mobile metal forms (mg/kg): $\mathrm{Cu}, 3.0 ; \mathrm{Ni}, 4.0 ; \mathrm{Zn}, 23.0$; Co, 5.0; $\mathrm{Cr}$ and $\mathrm{Pb}, 6.0$; Cd, 0.32 .

We proposed to assess the environmental hazard of the multielemental contamination of soil with mobile HMs using the Equation (3):

$$
Z o=\Sigma p * K o
$$

which represent the sum of the values of Ko $>1$ multiplied by their weights $p$, which depend on the hazard classes of the elements ( $p=1.5$ for the elements of hazard class I, and $p=1.0$ for the elements of hazard class II) [41].

The statistical analysis of the diversity of diatom algae depending on soils properties $(\mathrm{pH}$, exchangeable ammonium) and soil contamination with HMs and salts was performed by the regression tree method using S-Plus software (MathSoft, 1999). The method reveals the factors most significantly affecting the resultant index. The plotting of dendrogram is based on the sequential bipartition of the initial data set with observations of grouping and dependent variables.

\section{Results and Discussion}

\subsection{Main Physicochemical Parameters and the Contamination of Urban Soils}

Most of the studied soils have neutral reaction. All the soils were not salinized at the moment of study, but the significant proportions of the ions $\mathrm{Na}^{+}$and $\mathrm{Cl}^{-}$in the water extract (Table 1) indicate seasonal flooding of soils because of the use of deicers.

\begin{tabular}{|c|c|c|c|c|}
\hline Land-use zone & $\mathrm{pH}_{\text {water }}$ & Soluble salts, \% & Water extract composition & $\mathrm{N}_{\text {water-sol. }}+\mathrm{N}_{\text {exch. }}, \mathrm{mg} / \mathrm{L}$ \\
\hline $\begin{array}{l}\text { Industrial } \\
(n=1)\end{array}$ & 7.0 & 0.03 & $\mathrm{HCO}_{3}-\mathrm{Ca}$ & 5.28 \\
\hline $\begin{array}{l}\text { Traffic } \\
(n=5)\end{array}$ & $\frac{7.1}{6.6-7.7}$ & $\underline{0.03-0.06}$ & $\mathrm{Cl}-\mathrm{HCO}_{3}-\mathrm{Ca}-\mathrm{Na}$ & $\frac{7.09}{3.97-14.32}$ \\
\hline $\begin{array}{l}\text { Residential } \\
\quad(n=6)\end{array}$ & $\frac{6.8}{6.6-7.5}$ & $\frac{0.06}{0.04-0.09}$ & $\begin{array}{c}\mathrm{HCO}_{3}-\mathrm{Na}-\mathrm{Ca} \text {, } \\
\mathrm{Cl}-\mathrm{HCO}_{3}-\mathrm{Ca}-\mathrm{Na} \text {, } \\
\mathrm{Cl}_{-} \mathrm{HCO}_{3}-\mathrm{Na}-\mathrm{Ca} \text {, } \\
\mathrm{NO}_{3}-\mathrm{HCO}_{3}-\mathrm{K}-\mathrm{Ca}\end{array}$ & $\frac{9.74}{5.43-15.32}$ \\
\hline $\begin{array}{l}\text { Recreation: } \\
\text { park }(n=3)\end{array}$ & $\frac{6.4}{6.4-6.5}$ & $\frac{0.05}{0.04-0.07}$ & $\begin{array}{l}\mathrm{HCO}_{3}-\mathrm{Na}-\mathrm{Ca} \text {, } \\
\mathrm{Cl}-\mathrm{HCO}_{3}-\mathrm{Ca}-\mathrm{Na}\end{array}$ & $\frac{8.55}{5.03-15.25}$ \\
\hline $\begin{array}{l}\text { River valley } \\
\quad(n=3)\end{array}$ & $\frac{7.0}{6.4-7.5}$ & $0 . \underline{0.06}$ & $\begin{array}{c}\mathrm{HCO}_{3}-\mathrm{Ca} \\
\mathrm{Cl}-\mathrm{HCO}_{3}-\mathrm{Na}-\mathrm{Ca}\end{array}$ & $4.5 \frac{5.75}{4-7.18}$ \\
\hline
\end{tabular}

Table 1. Physicochemical properties and composition of water extract from the surface (0- to 3-cm) layer of soils in different land-use zones of Moscow.

The mean values and the variation ranges are given above and under the line, respectively. 


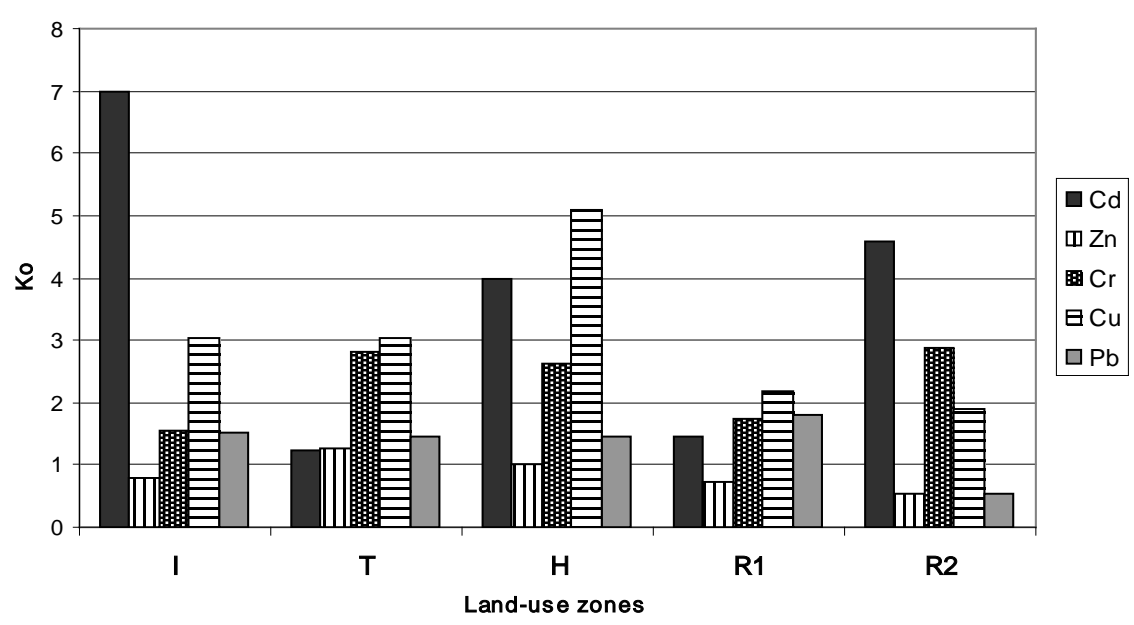

Figure 2. Environmental hazard factors $(\mathrm{Ko})$ for mobile HMs in the soils of different land-use zones of Moscow: (I) industrial; (T) traffic; (H) residential; (R1) and (R2) recreation (1, park; 2 , small river valley).

The physicochemical properties of soils vary among the different land-use zones. So, the soils in the industrial zone have the $\mathrm{HCO}_{3}$-Ca composition of water-soluble salts and very low contents of water-soluble and fixed forms of mineral nitrogen. The $\mathrm{Cl}-\mathrm{HCO}_{3}$-Ca-Na composition of water-soluble salts, weakly alkaline reaction in some cases, and the high variability of mineral nitrogen forms are typical for the soils of the traffic zone. An even higher spatial heterogeneity of physicochemical properties is noted in the soils of the residential and recreation zones. This is manifested in the diversity of both the contents of mineral nitrogen forms and the composition of water-soluble salts, which is related to the input of nitrogen with excrements of domestic animals into soils and to the differences in the intensity of seasonal soil salinization. The soils of the park are characterized by a weakly acid reaction typical for the slightly disturbed soddy-podzolic soils under forest vegetation.

High contents of some mobile HMs are observed in all soils. Their proportions vary among the different land-use zones, as can be judged from their environmental hazard factors (Figure 2). The values of Ko suggest that the soils contain the most hazardous concentrations of the following $\mathrm{HMs}$ : $\mathrm{Cd}$ and $\mathrm{Cu}$ in the industrial zone; $\mathrm{Cu}$ and $\mathrm{Cr}$ in the traffic zone; $\mathrm{Cu}, \mathrm{Cd}, \mathrm{Cr}$ in the residential and in the recreation zones.

According to the environmental hazard of integrated contamination with mobile HMs estimated by the value of $\mathrm{Zo}$, the studied soils can be arranged in the following series: soils of the industrial and residential zones $(\mathrm{Zo}=$ 19.2 - 19.6) > soils of the traffic zone (13.3) > soils of the recreation zone (11.2).

\subsection{Features of Algal-Cyanobacterial Communities}

The algal-cyanobacterial communities of undisturbed soddy-podzolic soils predominant in the soil cover of the taiga zone are characterized by the high species diversity (including yellow-green algae), the relatively low proportion of nonheterocystic cyanobacteria in phototrophs, the multispecies complex of dominant species [42] [43], the presence of acidophilic species (indicators of acidity) and the low diversity of halophilic species of diatom algae.

The anthropogenic impact on soils provokes the reorganization of algal-cyanobacterial communities with changes in the above parameters, as observed in the studied soils of Moscow. In spring, in the absence of closed grass cover, diatom and green algae are most predominant at the high soil water content in all the land-use zones (Table 2).

In most of the studied soils in Moscow, diatom algae dominate in the algal-cyanobacterial communities (Table 3). The domination of diatom algae in algoflora was observed in ponds of Moscow in spring [44], which was attributed to the high anthropogenic load on the water bodies.

The main parameters of the algal-cyanobacterial communities vary among the soils of different land-use zones in Moscow. The industrial zone is characterized by the least species diversity of algae, especially yellowgreen algae, and the highest proportion of cyanobacteria in the algal-cyanobacterial communities (Table 2). Cyanobacteria are nonheterocystic species from the genera Leptolyngbya, Phormidium and Microcoleus. A sin- 
gle species is dominant (Table 3). In the complex of diatom algae, acidophilic species are absent; alkaliphiles make up $60 \%$ of the total number of species, which is due to soil alkalization. Halophobic species are also absent; on the contrary, the halophilic group is abundant ( $40 \%$ of the total number of diatom species). This indicates chronic seasonal anthropogenic salinization of the soil.

In the traffic zone, the total species diversity of algal-cyanobacterial communities significantly increases, mainly due to diatom and green algae, the proportion of cyanobacteria being decreased. The number of dominant species increases (Table 3). Acidophilic species are also absent among the diatom algae. However, the

Table 2. Composition of algal-cyanobacterial communities in the surface (0- to 3-cm) layer of soils in different land-use zones of Moscow.

\begin{tabular}{|c|c|c|c|c|}
\hline \multirow{2}{*}{$\begin{array}{c}\text { Components of algal-cyanobacterial } \\
\text { communities }\end{array}$} & \multicolumn{4}{|c|}{ Land-use zones } \\
\hline & Industrial & Traffic & Residential & $\begin{array}{c}\text { Recreation } \\
\text { (park + river valley) }\end{array}$ \\
\hline \multicolumn{5}{|l|}{ Algae: } \\
\hline diatom & $\underline{8}$ & $\underline{21}$ & $\underline{15}$ & $\underline{23}$ \\
\hline green & 20.0 & $\underline{13}$ & $\frac{11}{28.2}$ & $\frac{13}{28.3}$ \\
\hline yellow-green & $\underline{1}$ & $\frac{2}{4.8}$ & 23.1 & $\frac{9}{19.6}$ \\
\hline Cyanobacteria & 20.0 & 14.3 & $\stackrel{4}{10.3}$ & $\underline{1}$ \\
\hline Total & $\underline{15}$ & $\underline{42}$ & $\underline{39}$ & $\frac{46}{100.0}$ \\
\hline
\end{tabular}

The number of species and their percentage of the total number of species are given above and under the line, respectively.

Table 3. Dominant algal species in the algal-cyanobacterial communities of soils in different land-use zones of Moscow.

\begin{tabular}{|c|c|c|c|c|}
\hline \multirow{2}{*}{ Algal species } & \multicolumn{4}{|c|}{ Land-use zones } \\
\hline & Industrial & Traffic & Residential & Recreation \\
\hline \multicolumn{5}{|l|}{ Diatoms } \\
\hline Achnanthes lanceolata & & + & & + \\
\hline Navicula atomus & & & + & \\
\hline Navicula minima & & & + & + \\
\hline Pinnularia lagerstedtii & & + & + & \\
\hline Caloneis bacillum & & & & + \\
\hline Amphora sp. & & & & + \\
\hline Nitzschia pusilla & + & + & + & \\
\hline \multicolumn{5}{|l|}{ Green } \\
\hline Chlorococcum sp. & & & & + \\
\hline Pseudococcomyxa simplex & & & + & + \\
\hline Stichococcus minor & & & & + \\
\hline \multicolumn{5}{|l|}{ Yellow-green } \\
\hline Xanthonema bristolianum & & & & + \\
\hline Total & 1 & 3 & 5 & 8 \\
\hline
\end{tabular}


proportion of alkaliphilic and halophilic species decreases (to $40 \%$ and $25 \%$, respectively), which indicates some decrease in the alkalization and seasonal salinization of soil.

In soils of the residential zone, a high species diversity of algal-cyanobacterial communities remains, but their structure significantly changes: the proportion of yellow-green algae abruptly increases, and that of cyanobacteria decreases further. The number of the dominant species increases (Table 3). Among the diatom algae, acidophilic species appears (10\% of the total abundance); the proportion of alkaliphiles decreases to $30 \%$. The number of halophilic diatom species decreases further (to $18 \%$ of the total number of diatom species). The composition and structure of algal-cyanobacterial communities reflect a further decrease in the effect of alkalization and seasonal salinization of soil.

The algal-cyanobacterial communities of soils in the recreation zone are characterized by the highest species diversity and the lowest abundance of cyanobacteria. The latter is due to both natural factors, such as the weakly acid reaction of soil in the park, and anthropogenic factors, including the decrease in soil contamination with mobile HMs. In the algal-cyanobacterial communities of the park, small green and yellow-green algae prevail, which is typical for forest soddy-podzolic soils [43]. In the complex of diatom algae in the park soils, the proportion of alkaliphilic species decreases to $25 \%$, and the halophilic species make up $20 \%$. This is due to the lower intensity of soil alkalization in the park and the retention of the same level of seasonal salinization that is observed in soils of the residential zone.

By the totality of parameters, the algal-cyanobacterial communities of the undisturbed soddy-podzolic soils, prevailing in the soil cover beyond the city, are most different from the soils communities of the industrial zone and least different from those of the recreation zone.

The values of the Jaccard similarity coefficient $(\mathrm{KJ})$ show a low similarity in the species composition of algae and cyanobacteria in the soils of different land-use zones of Moscow (Table 4).

Thus, according to the degree of transformation of the algal-cyanobacterial communities in the soils, the functional zones of Moscow are arranged in the following series: industrial $>$ traffic $>$ residential $>$ recreation.

Multifactor regression analysis showed that the number of diatom species is determined by soil acidity: it is significantly smaller in a weakly acidic environment $(\mathrm{pH}<6.7)$ than in neutral and alkaline environments. The contamination of soils with mobile $\mathrm{Cu}$ and $\mathrm{Zn}$ plays a significant role. Under slightly acid conditions, the number of diatom species primarily depends on the content of mobile copper forms: at $\mathrm{CCu}>7.0$, the diatoms are more abundant. At $\mathrm{CCu}<7.0$, their diversity also depends on the content of mobile $\mathrm{Zn}$ forms. The values of $15.4-15.9 \mathrm{mg} / \mathrm{kg}$ are critical for mobile zinc: when they are exceeded, the number of diatom species decreases; a higher effect of soil contamination with $\mathrm{Zn}$ is noted under neutral and slightly alkaline conditions (Figure 3).

Table 4. The similarity coefficients $(K j)$ of species composition for algal-cyanobacterial communities in different land-use zones of Moscow.

\begin{tabular}{ccccc}
\hline Land-use zone & Industrial & Traffic & Residential & Recreation \\
\hline Industrial & - & 0.33 & 0.23 & 0.17 \\
Traffic & & - & 0.33 & 0.28 \\
Residential & & - & 0.33 \\
Recreation & & & - \\
\hline
\end{tabular}

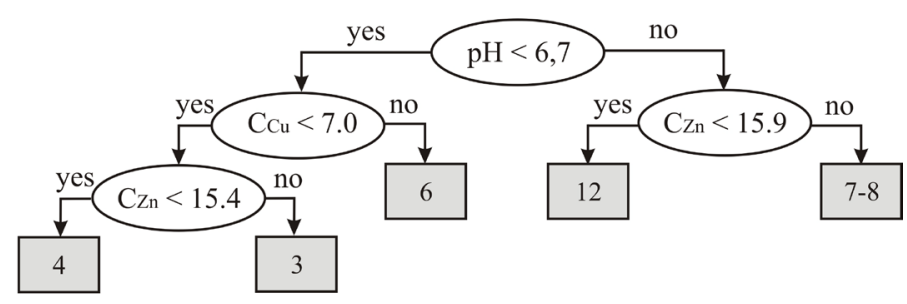

Figure 3. Mean number of diatom algal species (in rectangles) depending on the reaction of soils and their contamination with HMs (concentrations of mobile $\mathrm{Zn}$ and $\mathrm{Cu}$ ) in Moscow (in ellipses). 
Table 5. Composition and relative abundance of nano- and microfauna and fungal mycelium in the surface (0- to 3-cm) layer of soils in different land-use zones of Moscow.

\begin{tabular}{ccccc}
\hline \multirow{2}{*}{ Microbiota components } & \multicolumn{4}{c}{ Land-use zones } \\
\cline { 2 - 5 } & Industrial & Traffic & Residential & Recreation \\
\hline Fungal mycelium: & - & & 1 & \\
colorless & 1 & 1 & 1 & 1 \\
colored & & 2 & & 1 \\
Nano- and microfauna: & - & 1 & - & 2 \\
naked ameba & 1 & 1 & 1 & 1 \\
testate ameba & 2 & 1 & 1 & 2 \\
nematodes & - & - & - & \\
rotifers & & &
\end{tabular}

Relative abundance: (1) rare; (2) quite often; (-) absent in the soil.

\subsection{Composition and Abundance of Nano- and Microfauna and Microscopic Fungi}

It is known that in the taiga zone, the highest diversity is observed for the nano- and microfauna in undisturbed and slightly disturbed soils; micromycetes with colorless mycelium are prevalent [5] [6] [8] [10]. The anthropogenic impact on the soils in cities affects the composition and abundance of these groups of organisms. The changes are also observed in the soils of Moscow (Table 5).

The soils of the industrial zone are characterized by the poorest composition of nano- and microfauna. The micromycetes include only species with colored mycelium. At the same time, the highest relative abundance of nematodes is observed in these soils. In the soils of the traffic zone, the diversity of nanofauna slightly increases, the abundance of nematodes decreases, and colorless mycelium appears which indicates some decrease in the total level of anthropogenic load on the soils. In the residential zone, similar abundances of colored and colorless mycelium are observed. The most various compositions of nano- and microfauna is in the recreation zone, where fungi with colorless mycelium prevail and basidiomycete mycelium appears, which indicates a relatively low anthropogenic impact on the soil.

The obtained data show that soil microbiota components differently respond to the integrated impact of anthropogenic factors on the urban soils. Micromycetes with colored mycelium are highly resistant to this impact, which agrees with the available literature data [9] [10] [45]. Representatives of the microfauna relatively resistant to anthropogenic changes of urban soils on the results of our study are nematodes. This is confirmed by the data obtained in the city of Kirov [46].

According to the degree of transformation of nano- and microfauna and the relative abundances of colored and colorless fungal mycelium, the soils in different land-use zones of Moscow are arranged in the same series as in accordance with the parameters of algal-cyanobacterial communities.

\section{Conclusions}

The comparison of the results of physicochemical and biological studies of soils in Moscow shows that they are complementary and necessary for assessing the environmental status of soils under urban conditions.

Physicochemical methods provide indications of the main anthropogenic changes in soil properties and levels of their contamination with HMs and deicers. In the studied soils of Moscow, $\mathrm{Cu}, \mathrm{Cd}$, and $\mathrm{Cr}$ are the priority pollutants, whose concentrations exceed the MPCs. The integrated degree of contamination with mobile HMs is the highest in the industrial and residential zones $(Z o=19.2-19.6)$ and lowest in the recreation zone $(Z o=$ 11.2).

However, the physicochemical studies do not reliably estimate the differences in labile parameters (acid-base conditions, contents of water-soluble salts and mineral nitrogen forms) among the different land-use zones of the city because of the high spatial variation of the data. 
Technogenic load causes changes in the composition and relative abundances of active soil microbiota, which are the highest in soils of the industrial zone and lowest in the recreation zone. In spring, before the appearance of closed grass cover, diatom and green algae, nonheterocystic cyanobacteria, micromycetes with colored mycelium, and nematodes are most resistant to anthropogenic impacts. In soils of all land-use zones of the city, the algal-cyanobacterial communities include halophilic algal species, which indicate chronic seasonal anthropogenic salinization of soils with deicing agents. The diversity of diatom algae forming the basis of algal-cyanobacterial communities in all of the studied urban soils in spring depends on the acid-basic conditions and the contents of mobile copper and zinc forms.

Using the data on the composition and structure of algal-cyanobacterial communities, the composition and abundance of soil nano- and microfauna, and the ratio between the colored and colorless fungal mycelium, we determine the response of microbiota to the alkalization, pollution, and seasonal salinization of soils in different land-use zones and thus comprehensively estimate the degree of anthropogenic transformation of the studied soils. From the obtained results, the land-use zones of the city are arranged according to the decreasing degree of technogenic transformation of soil microbiota communities in the following series: industrial zone $>$ traffic zone $>$ residential zone $>$ recreation zone.

\section{Acknowledgements}

This study was supported by the Russian Foundation for Basic Research and the Russian Geographical Society (project No. 13-05-41191-RGO).

We were grateful to D. Vlasov for his help in preparation of figures.

\section{References}

[1] Gerasimova, M.I., Stroganova, M.N., Mojarova, N.V. and Prokofieva, T.V. (2003) Anthropogenic Soils: Genesis, Geography, Remediation. Oikumena, Smolensk, 266 p. (In Russian)

[2] Kosheleva, N.E., Kasimov, N.S. and Vlasov D.V. (2015) Factors of the Accumulation of Heavy Metals and Metalloids at Geochemical Barriers in Urban Soils. Eurasian Soil Science, 48, 476-492. http://dx.doi.org/10.1134/S1064229315050038

[3] Khaibullina, L.S., Sukhanova, N.V. and Kabirov, R.R. (2011) Flora and Syntaxonomy of Soil Algae and Cyanobacteria in Urbanized Areas. Gilem, Ufa, 216 p. (In Russian)

[4] Domracheva, L.I., Dabakh, E.V., Kondakova, L.V. and Varaksina A.I. (2006) Algal-Mycological Complexes in Soils upon Their Chemical Pollution. Eurasian Soil Science, 39, 91-97. http://dx.doi.org/10.1134/S1064229306130151

[5] Kuznetsova, L.V. and Krivolutskii, D.A. (1982) Invertebrate Animals as Environmental Bioindicators in Moscow. Bioindication of the Environmental State in Moscow and Moscow Region, Moscow, 54-57. (In Russian)

[6] Geltser, Y.G. and Yakovlev, A.S. (1996) The Significance of Biodiversity for Soil Diagnostics. Eurasian Soil Science, 29, 735-742.

[7] Andrievskii, V.S. and Syso, A.I. (2012) The Effect of Different Types of Antropogenic Changes in Soils on Communities of Oribatids in Urban Ecosystems. Contemporary Problems of Ecology, 5, 574-579. http://dx.doi.org/10.1134/S1995425512060030

[8] Marfenina, O.E. (2005) Anthropogenic Ecology of Soil Fungi. Meditsina Dlya Vsekh, Moscow, 195 p. (In Russian)

[9] Shirokikh, A.A. (2012) Fungi in Urboecosystems. In: Ashikhmina, T.Y. and Domracheva, L.I., Eds., Features of Urboecosystems in the Southern Taiga Subzone of Northeastern Europe, VyatGGU, Kirov, 104-119. (In Russian)

[10] Terekhova, V.A. (2007) The Importance of Mycological Studies for Soil Quality Control. Eurasian Soil Science, 40, 583-587. http://dx.doi.org/10.1134/S1064229307050158

[11] Shtina, E.A. (1990) Soil Algae as Ecological Indicators. Botanicheskii Zhurnal, 75, 441-452. (In Russian)

[12] Kabirov, R.R. and Shilova, I.I. (1994) Communities of Soil Algae in the Areas of Industrial Enterprises. Ekologiya, 6, 16-20. (In Russian)

[13] Van Straalen, N.M. and Krivolutsky, D.A. (1995) Bioindicator Systems for Soil Pollution. Kluwer Academic Publishers, Dordrecht, 500 p.

[14] Kabirov, R.R. (1991) Soil Algae of Technogenic Landscapes. S.D. (Biol.) Dissertation, St. Petersburg State University, St. Petersburg, 333 p. (In Russian)

[15] Kabirov, R.R. and Sukhanova, N.V. (1997) Soil Algae of Urban Lawns. Algologiya, 6, 175-182. (In Russian) 
[16] Trukhnitskaya, S.M. and Chizhevskaya, M.V. (2008) Algoflora in the Recreation Areas of the Krasnoyarsk Urboecosystem. KrasGAU, Krasnoyarsk, 135 p. (In Russian)

[17] Domracheva, L.I., Kondakova, L.V., Zykova, Y.N. and Efremova, V.A. (2012) Algal-Cyanomycological Complexes of Urban Soils. In: Ashikhmina, T.Ya. and Domracheva, L.I., Ed., Features of Urboecosystems in the Southern Taiga Subzone of Northeastern Europe, VyatGGU, Kirov, 120-168. (In Russian)

[18] Moskvich, N.P. (1972) Algological Characterization of the Sanitary State of Soils in Settlements. PhD Disertation, Institute of General and Communal hygiene RAMS, Voroshilovgrad. (In Russian)

[19] Shekhovtsova, O.G. (2012) Soil Algosynusia of Urboecosystems in the Donetsk Azov Region (with Mariupol as an Example). Biologicheskii Vestnik Melitopolskogo Gosudarstvennogo Pedagogicheskogo Universiteta im. Bogdana Khmelnitskogo, 3, 108-118. (In Russian)

[20] Yakovlev, A.S. (1997) Biological Diagnostics of Virgin and Anthropogenically Modified Soils. S.D. (Biol.) Dissertation, Moscow State University, Moscow, 335 p. (In Russian)

[21] Iliyna, I.N., et al. (2000) Ecological Atlas of Moscow. ABF, Moscow, 96 p. (In Russian)

[22] Deev, S.V. (2013) Great Atlas of Moscow. Feoriya, Moscow, 1000 p. (In Russian)

[23] Nikolaev, L.F., Otskheli, O.V., Porshalaeva, E.B., et al. (1998) Deicing Agents and Their Effect on the Natural Environment. Dialog-MGU, Moscow, 60 p. (In Russian)

[24] Chernousenko, G.I., Yamnova, I.A. and Skripnikova, M.N. (2003) Anthropogenic Salinization of Soils in Moscow. Eurasian Soil Science, 36, 92-100.

[25] Smagin, A.V., Azovtseva, N.A., Smagina, M.V., Stepanov, A.L., Myagkova A.D. and Kurbatova, A.S. (2006) Criteria and Methods to Assess the Ecological Status of Soils in Relation to the Landscaping of Urban Territories. Eurasian Soil Science, 39, 539-551. http://dx.doi.org/10.1134/S1064229306050115

[26] Nikiforova, E.M., Kasimov, N.S. and Kosheleva, N.E. (2014) Long-Term Dynamics of the Anthropogenic Salinization of Soils in Moscow (by the Example of the Eastern District). Eurasian Soil Science, 47, 203-215. http://dx.doi.org/10.1134/S1064229314030041

[27] Kasimov, N.S. (1995) Ecogeochemistry of Urban Landscapes. MGU, Moscow, 336 p. (In Russian)

[28] Lund, J.W.G. (1945) Observation on Soil Algae. 1. The Ecology, Size and Taxonomy of British Soil Diatoms. New Phytologist, 44, 196-219. http://dx.doi.org/10.1111/j.1469-8137.1945.tb05033.x

[29] Gollerbakh, M.M. and Shtina, E.A. (1969) Soil Algae. Nauka, Leningrad, 228 p. (In Russian)

[30] Gärtner, G. (1996) Soil Algae. In: Schinner, F., Öhlinger, R., Kandeler, E. and Margesin, R., Ed., Methods in Soil Biology, Springer, Berlin, 295-305. http://dx.doi.org/10.1007/978-3-642-60966-4_19

[31] Bishoff, H.W. and Bold, H.C. (1963) Some Soil Algae from Enchanted Rock and Related Algae Species. University of Texas Publication No. 6318, 43-59.

[32] Ettl, H. and Gärtner, G. (1995) Syllabus der Boden-, Luft- und Flechtenalgen. G. Fischer, Stuttgart, Jena, New York, $722 \mathrm{~s}$.

[33] Krammer, K. (2000) Diatoms of Europe. Vol. 1: The Genus Pinnularia. A.R.G. Gantner Verlag. Kommanditgesellschaft, Königstein, 1-703. http://dx.doi.org/10.1023/A:1008914531485

[34] Krammer, K. and Lange-Bertalot, H. (1997) Bacillariophyceae, Teil1: Naviculaceae. Vol. 2, In: Ettl, H., Gerloff, J., Heyning, H. and Mollenhauer, D., Ed., Süsswasserflora von Mitteleuropa (Begründet von A. Pascher), Spektrum Akademischer Verlag, Nachdr. Heidelberg, 1-876.

[35] Anagnostidis, K. and Komárek, J. (1988) Modern Approach to the Classification System of Cyanophytes. 3-Oscillatoriales. Algological Studies, 50-53, 327-472.

[36] Vorob'eva, L.A. (Ed.) (2006) Theory and Practice of the Chemical Analysis of Soils. GEOS, Moscow, 400 p. (In Russian)

[37] Barinova, S.S., Medvedeva, L.A. and Anisimova O.V. (2006) Biodiversity of Environmental Indicator Algae. Pilies Studio, Tel Aviv, 498 p.

[38] Kostikov, I.Y. (1993) Soil Algae of the Lazovsky Nature Reserve (Far East, Russia). Algologiya, 3, 62-66. (In Russian)

[39] Jaccard, P. (1901) Distribution de la flore alpine dans le Bassin des Dranses et dans quelques regions voisines. Bulletin de la Société Vaudoise des Sciences Naturelles, 37, 241-272.

[40] Rusakov, N.V., Kryatov, I.A., Tonkopy, N.I., Gumarova, J.J., Pirtahiya, N.V. and Vesseloe, A.P. (2006) Hygienic Standards GN 2.1.7.2041-06 Maximum Permissible Concentration (MPC) of Chemicals in the Soil. Bulletin of Normative acts of Federal Bodies of Executive Power, 102006, 15 p. (In Russian)

[41] Vodyanitskii, Y.N. (2012) Standards for the Contents of Heavy Metals and Metalloids in Soils. Eurasian Soil Science, 
45, 321-328. http://dx.doi.org/10.1134/S1064229312030131

[42] Shtina, E.A. and Gollerbakh, M.M. (1976) Ecology of Soil Algae. Nauka, Moscow, 143 p. (In Russian)

[43] Aleksakhina, T.I. and Shtina, E.A. (1984) Soil Algae of Forest Biogeocenoses. Nauka, Moscow, 149 p. (In Russian)

[44] Romanova, O.L. (2005) Diatom Algae in the Artificial Water Bodies of Moscow. In: Genkal, S.I., Ed., Morphology, Systematization, Ontogenesis, Ecology and Biogeography of Diatom Algae: Theses IX School of Diatomologists from Russia and CIS Countries, Institute of biology of inland waters named after I. D. Papanin RAS, Borok, 54-55. (In Russian)

[45] Artamonova, V.S., Yu, D.L., Elizarova T.N. and Lyutykh I.V. (2010) Technogenic Salinization of Soils and Their Microbiological Characterization. Contemporary Problems of Ecology, 3, 323-330. http://dx.doi.org/10.1134/S1995425510030112

[46] Tselishcheva, L.G., Pestov, S.V. and Khodyrev, N.N. (2012) Zoocenoses of Urban Areas. In: Ashikhmina, T.Ya. and Domracheva, L.I., Ed., Features of Urboecosystems in the Southern Taiga Subzone of Northeastern Europe, VyatGGU, Kirov, 46-67. (In Russian) 